\title{
The Seventh Ray: A Mixed Reality initiation experience
}

\author{
Carl H. Smith \\ Director, Learning Technology \\ Research Centre (LTRC) \\ Principle Research Fellow, \\ Ravensbourne, London, UK \\ c.smith@rave.ac.uk
}

\author{
Sarah Janes \\ The Explorers Club \\ St Leonards on Sea \\ East Sussex \\ UK \\ sarahjanes@hotmail.com
}

\begin{abstract}
'Seventh Ray' is a Mixed Reality (MR) platform inspired by Mystery School initiation techniques of the ancient world. The platform employs the latest in perceptual and sensory augmentation technologies to explore the meaning and modern day significance of these ancient ceremonies. The historic texts provide a formula and the new technologies provide the tools to revive these rites into previously unimaginable formulations. The Seventh Ray seeks to explore the combined power of drama with the particular state of awareness one feels when they fully inhabit a mixed reality. Might the MR brain exhibit closer parallels with the 'book reading brain' than that of the 'movie watching' one? The ancient texts give us a formula; the emerging technologies of VR and AR give us the tools to revive these ancient rites into unimaginable dimensions.
\end{abstract}

Mixed reality. Mystery schools. Eleusinian Mysteries.

\section{INTRODUCTION AND METHODOLOGY}

In the ancient worlds of Egypt, Mesopotamia, Greece and Rome there was a strong tradition of Mystery School training. This programme invokes a practice, which has lasted through most of human history and has spread across many diverse cultures. These systems of initiation can still be seen today in the spiritual doctrines of many Eastern cultures and such organisations and fraternities as Freemasonry, Anthroposophy, Theosophy and Rosicrucianism.

The question of what actually took place in the Mystery School initiations has generated a sizeable secondary literature; as a result these new liminal spaces provide fertile testing grounds for exploring the implications and outcomes of these 'initiation' practices.

Using carefully designed visual, audio and somatic stimuli, can we create within an individual - an experience of profound awe, rapture, direct contact with the divine, gnosis? Drawing material from the records of antiquity, personal descriptions of religious ecstasy and accounts of spiritual enlightenment - Can a simulation of a certain atmosphere, key symbology, subtle manipulation of sensation and audio-visual stimuli induce a state of transformation?

There is something dreamlike about the experience of VR and MR; it feels engaging, as though one were inhabiting the imagination. It is an 'active' media, and this is a very key part of our experience that of dream designing where the participant is active rather than 'passive' observer. VR can deliver the dream state to the fully conscious observer, something like a lucid dream level of awareness.

'Seventh Ray' is designed to provide a catalysing experience, incorporating the rich symbolism of the Mystery Traditions into a Cyberdelic first-hand experience of an 'other' reality. Using the information that is available about the rituals and devices employed during mystery initiation ceremonies of ancient Greece, we aim to distil the essential elements for a contemporary participant to experience something akin to that felt by an ancient initiate.

\section{THE STAGES OF INITIATION RITUAL}

There are well-documented stages of initiation ritual and upon any given path, the elements of each step have been carefully plotted to deeply 
impact the consciousness of the participant. Our experience will be composed of seven stages, reflecting the Seven Rays of Gnostic Mysticism which offers one of the clearest systems of initiatory rites.

(i) Desire for knowledge: The participant must make a formal declaration that they wish to be initiated into the Mysteries.

(ii) Pledge of secrecy: Once accepted, the participant must make a vow of silence, they must not speak of this to any other non-initiate. This act compels the participant to connect with their inner selves and a private world. The simple covenant activates self-awareness.

(iii) Deprived of sight: Blindfolded, the participant puts their trust in their guide, to take them into the unknown. Vulnerability and sense deprivation create a certain intensity, which heightens the richness of the experience within the other senses. The participant is mildly disorientated on a circuitous route, recalling the labyrinth and accompanied by mysterious sounds and sensations. This is the journey through the underworld.

(iv) Reveal of the other realm: A paradisal vision of the other world. A glimpse of Eden. This intense visual feast is laden with the symbols of connectedness and eternity. A re-emerging into immortal life.

(v) Manifestation: Within this realm, thoughts become manifest. Material is fluid and multi-dimensional, sight is unbound from the usual human limitations.

(vi) Healing: This fluid reality flows through the participant. The solidity of their own body dissolves and its continuity with the rest of creation witnessed. The subject is reset in perfection. The body is experienced as timeless pure light.

(vii) Contact with God: The participant encounters an entity and is re-conceived as an immortal aspect of God. Kneeling in devotion - the subject experiences radiating love for all.

From the Egyptian - The Book of Coming Forth by Day (or into the Light) an important quote which this project aims to crystallise... "Strive to see with the inner eye, the heart. It sees the reality not subject to emotional or personal error; it sees the essence. Intuition then is the most important quality to develop."

'Initiation' has been a part of human culture for centuries and underpinning every expression of the process is the core precept that 'you have to die in order to live.' This is not a physical death, but rather the deliberate obliteration of the Ego - which might involve using intense fear, intoxication, sensory deprivation or utter surrender as a tool. Essentially, the release of Ego and overidentification with the Self, provides an individual with a spiritual rebirth and a personal experience of the divine potential integrated within. An overidentification with mortal flesh, blood and a personal thought world that one believes to be the sum of oneself, is seen as the root cause of humanity's misery.

Since antiquity much has been written about the positive effects of the initiation experience upon the individual. Our experiment is an attempt to provide these transcendental and liberating gifts in a modern way for those who may not even be aware that anything is missing. The positive effect we might recognise contemporarily might be similar for some as facing and overcoming the worst fear. If our worst fear is dying and we pass through that process and come through the other side, our joy in life comes through our releasing fear. How can we use technology to both face and process our worst fears?

The umbilical cord between our unconscious and conscious selves has been severed. Something even ancient peoples could identify in the earliest of times. The true purpose of initiation is integration and we know this as the initiator of initiation is the hierophant, or psychopomp. Initiation requires a trusted guide. How can technology help us to reintegrate the unconscious and conscious selves?

We can see in ancient stories and ideas about the cosmic twins, a narrative representing the idea of human duality. We are part mortal, part divine and we need these two aspects to discover one another to become whole, individuated, healthy people. In initiation we come out of duality into union, it is a replay of the conception and birth we passed through blindly at our beginning. Here we have the opportunity for a rebirth with our eyes wide open.

\section{THE ELEUSINIAN MYSTERIES}

One of the most famous Mystery traditions, The Eleusinian Mysteries centre around the myth of Demeter and Persephone a fertility cult of sorts with a core drama of Persephone's abduction by Hades. The abduction by Hades - God of death and the underworld) of the flower-painting daughter of the goddess of fertility and agriculture, represents the retreating sap of Autumn, the pooling of life forces into the Earth, the dominion of the Gods over the planet's fate. Demeter's petitioning and drought mongering finally results in Persephone's part-time release and Spring and fertility return to the land for the duration of her liberty. The cycle continues thus. 
It is not necessary here to go into the intricate complexities of Eleusinian rites or the grading system, which has a parallel in the hierarchical structure of Freemasonry, but the essence of passing through stages and attaining grades is something essential to the character of the institution.

For the neophyte there was a long period of observation and a critical emphasis on maintaining the utmost secrecy about proceedings. The Mysteries of Eleusis are one of the oldest traditions of Ancient Greece and there are several ideas as to it's provenance, some believing it to be connected to the poppy goddesses of Minoan culture of Crete and some relating it to earlier agrarian cults.

\section{PREPARING THE CONTEXT}

Much was done in preparation for taking part in the Mysteries, periods of purification, fasting and dedication. There were the Lesser Mysteries of Spring first - during 'the time of flowers' and participants took their first steps here towards initiation proper. It is said that the Lesser Mysteries were the trial in a sense for the Greater Mysteries, which took part in late summer. We know something about the various stages of the initiation, but we know very little of the true nature of the sacred objects and divine experiences of those within the initiation hall - the Telesterion. The penalty for divulging information about the core ritual of the Mysteries was death and for thousands of years this has remained a well-kept secret. Technology now enables us allows us to test different theories of what may have happened in these mystery schools.

The Greater Mysteries lasted ten days and had a well-delineated timetable. On day one the 'sacred objects' - only initiates know the true nature of these sacred objects - were brought from Eleusis to the temple at the base of the Acropolis in Athens.

When the festivities of the Epidauria festival had concluded, the group re-joined for the great procession, to the sanctuary of Demeter and her daughter Persephone. The procession was a journey of about 15 miles and was frequently interrupted for sacred bathing, sacrifices, dancing and libations. The group voice chanted - 'lakch', o lakche', invoking the god lakchos at the head of the procession, who was closely related to and sometimes identified with Dionysos. On this procession, the young mocked the old, there was a loosening of social standing, roles were reversed, participants were mocked as the crossed the bridge over the river.
The energies of a crowd-mentality and merging resulted in the participants dancing into the sanctuary. By nightfall the thousands of blazing torches produced a wonderful mesmerising effect. At the entrance to the Sanctuary was a well, the site for sacred dancing. The sacrifice of a bull, that was lifted up and had its throat slit the following evening marked the beginning of two days spent within the Telesterion, where the initiation process came to climax. Some suppose the dramatic scenes within the initiation hall were performances of the abduction of Persephone, and there is evidence pointing to the fact that initiates acted out the search for Persephone with there torches at night times in the surrounding area.

On the second night, in the darkness after Persephone is recovered some scholars believe a sacred phallus is revealed to the audience (others believe it was an ear of wheat) and when the torches are extinguished there took place a divine union (subterranean marriage) in the blackness and the birth of a divine child. As one Gnostic author put it, 'just as the hierophant [...] at Eleusis, when performing the great, unspeakable Mysteries amid great fire, calls out at the top of his voice: "the reverend goddess has given birth to a sacred boy, Brimo to Brimos, that is the strong one has born a strong child".

Studying the symbolic language of the Eleusinian Mysteries, the most essential stand-out symbols are that of agriculture, grain, fertility - represented with the phallus or ear of wheat, the sacrifice of animals returning their blood to the chthonic gods of the Earth, the colours of flowers and their seasonal withering away and, the process of decay and fertilization which ultimately produces rebirth as represented by the announcement of the birth of divine boy-child and the product of the union between light and dark, day and night - between Persephone and Hades.

\section{ORPHIC MYSTERIES AND THE ORACLE OF TROPHONIOS}

The Orphic Mysteries laid more emphasis on the pursuit of heavenly re-connection. Of re-awakening the memory of our divine origins. Much can be seen in the verses inscribed upon the Orphic Gold Tablets, little scrolls of pure gold upon which instruction for the afterlife were carried around by initiates on necklaces. One translation of the text on an Orphic gold tablet reads:

You will find on the right in Hades' halls a spring, and by it stands a ghostly cypress-tree, where the dead souls descending wash away their lives. Do not even draw nigh this spring (spring of Lethe) 
'forgetfulness'. Further on you will find chill water flowing from the pool of Mnemosyne (Memory): over this stand guardians. They will ask you with keen mind what is your quest in the gloom of deadly Hades. They will ask you for what reason you have come. Tell them the whole truth straight out. Say: 'I am the son of Earth and starry Heaven, but of Heaven is my birth: this you know yourselves. I am parched with thirst and perishing: give me quickly chill water flowing from the pool of Memory.' Assuredly the kings of the underworld take pity on you, and will themselves give you water from the spring divine; then you, when you have drunk, traverse the holy path which other initiates and bacchants tread in glory. After that you will rule amongst the other heroes.

This brings us to the Oracle at Trophonios where concepts of Memory and Forgetfulness are vital components; Lethe and Mnemosyne are goddess sisters demonstrating a polarity of necessity for the human condition. In order to liberate the divine, one must first forget oneself. In order to retain the wisdom revealed in the selfless state, one must remember.

At the Oracle of Trophonios supplicants were made to drink first from the spring of Lethe - the source of which being two water-courses running alongside the oracle site. Before descent into the Oracle chamber the participant drank from the spring of Mnemosyne - in order to recall everything they were about to witness, they were then lowered into this tiny dark chasm, filled with snakes, which were to be placated by honey cakes. The rushing water gurgled and whispered to the supplicant, within the flow some messages might be discerned, but overall the experience produced a hypnotic effect. When the supplicant was later removed from the hole it was said they were often terrified and incoherently babbling and jittery, they were placed in the 'Throne of Mnemosyne' so that they might recall the events that occurred in as sensible a manner as possible. From this information, the oracle attendants were able to construct an oracle and the participant was carted off to a nearby boarding house to regain their strength.

Strongly symbolic here is the personification of Memory and Forgetfulness, of the spring arising out from the underworld, of the spring as an opportunity to commune with Earth Magic, of the cadence of water, the sound language of real things. Sensory deprivation, being in the earth, sent into its darkness so that you might be reborn. Caves as entrance ways to the underworld. Springs and streams and waterways as the threads that weave us into our world. Snakes and serpents as messengers from these chthonic realms, snakes as divine creatures with a sacred connection to the gods of the underworld, messengers from the realms hidden from the living.

Mnemosyne is a fantastic symbol and reveals much about the nature of humanity. She is the daughter of Ouranos (Heaven) and Gaiea (Earth) this union produced the personification of Memory - in Mnemosyne was created language, it is said she gave all things names, and her skill is in 'sense-making'. She bestows those who worship her with great skills in oration and understanding, she's a psychopomp. Invoked before sleep to enable dreamers to recall their dreams. She can take you into the 'other' realms and back into reality, her sense-making helping you find the treasure of your divine inner nature. She is the mother of the Muses, with divine inspiration comes the greatest most devoted art, inspired music and heavenly dancing, there can be no creativity without the flow of divine inspiration.

\section{BAIA}

The Oracle of the Dead at Baia is a controversial site, with much speculation about its origins and use, but evidence points to the fact that it was a kind of Ancient Greek Disneyland version of Hades. A simulated environment designed so that supplicants could dramatically enter the underworld and return above ground alive and with a new sense of vigor and purpose. All sort of techniques were employed to make the experience as real as possible, there was a great solemnness in the attendance of the oracle and a journey deep underground, a procession into a recreation of the Styx, complete with ferryman and hot sulphurous waters - this attention to detail would have instilled a great sense of reverence in any person brave enough to enter the underworld alive. Whether the seeker was attempting to contact the gods or find out about future events, there must have been a compelling reason to subject your self to what seems like quite a thoroughly unpleasant experience.

The most essential aspects of this Oracle of the Dead cult at Baia are certainly once again this connection with the underground and Earthy powers. Entering into the earth as a gateway to the underworld, where souls retreat to die, as in the cycles illustrated by the Demeter and Persephone story, when the life-force ebbs, it returns to the Earth and is reborn, in a new form. Searching in the labyrinth of the underworld, making some union and starting all over again. 


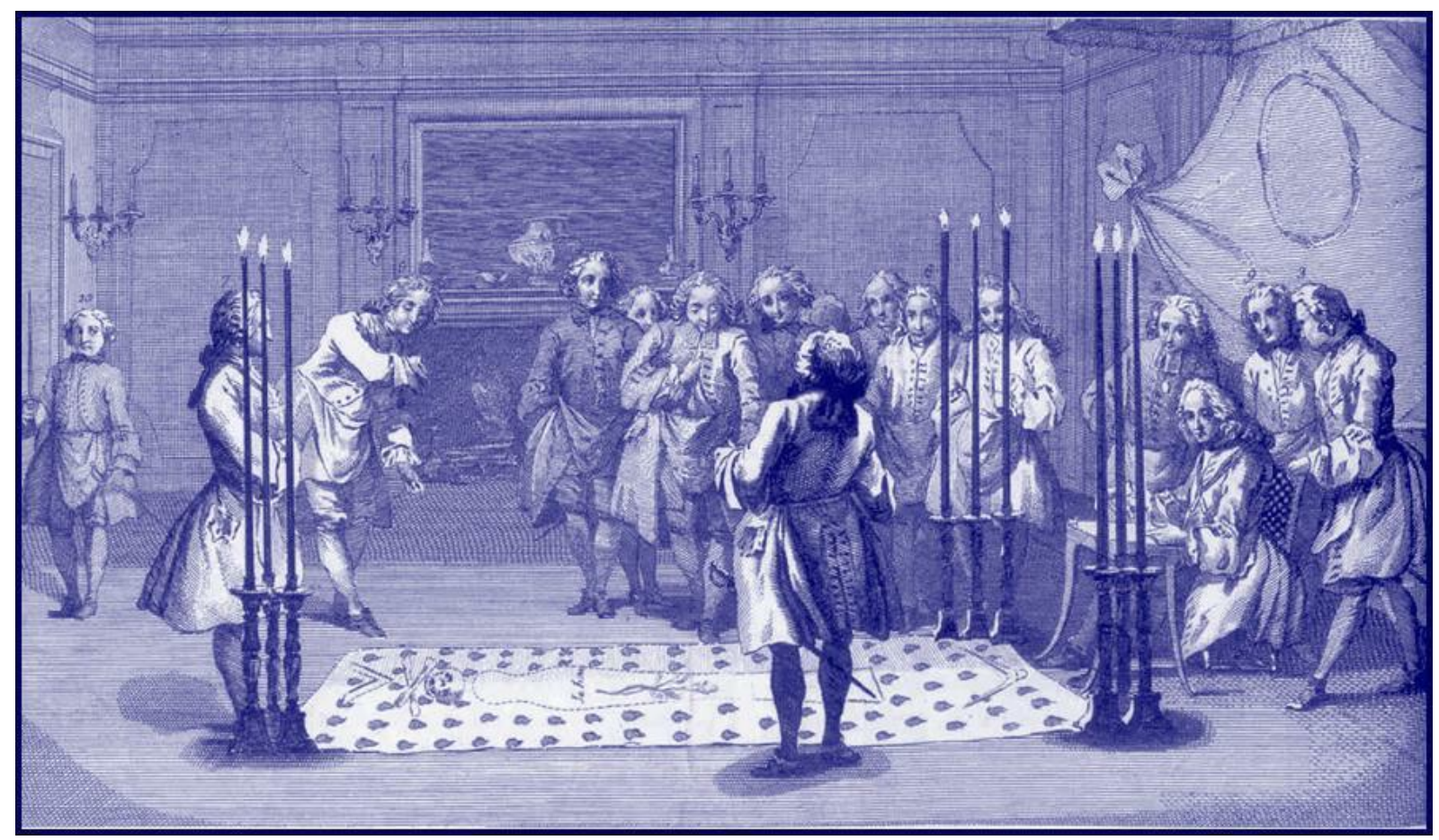

(a)

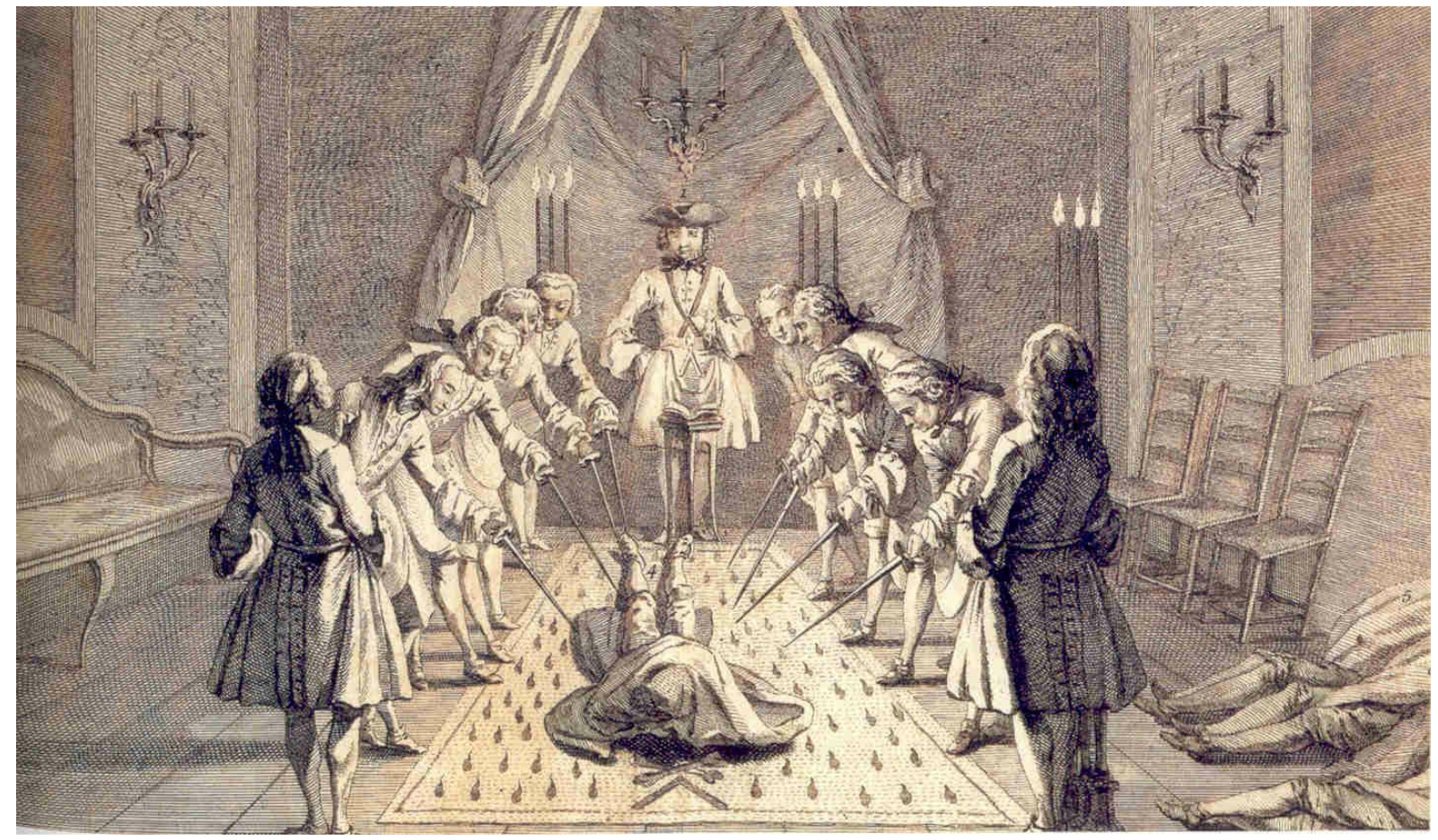

(b)

Figure 1: Assembly of Free Masons for the Initiation of a Master, from 'The Ceremonies of Religion \& Custom', c.1733 Stapleton Collection. Group scenes of initiation - including illustrated and reimagined depictions of Freemasonry, Mithraism, Druid and Rosicrucian initiation rites. These staged performances are designed to heighten the intensity of the initiatory experience and will be preceded by a long period of preparatory activity, research and personal development. 


\section{SAMOTHRACE}

One of the most enigmatic cults of the ancient world is the Sanctuary of the Great Gods, an island sanctuary in Thrace, a cult centre which seems to have emerged out of a pre-Greek and very ancient Mother Goddess tradition, worship of the Great Gods is worship of the Earthly powers, the mother is the mother of mountains, a great emphasis is put upon magnetic forces. Initiates to Samothrace were endowed with magnetic iron rings and the magnetic iron veins running through the landscape of this site were important evidence of its power.

The great mother, like the Anatolian Cybele (Magna Mater), is pictured on a throne, with a lion at her side. Another of the great gods is a male, symbol of fertility, represented by the phallus; and more take the shape of divine twins, saviour of mariners - with which the sanctuary was especially popular. We know something of the initiatory rites at Samothrace, it was not as expensive or exclusive as the Eleusinian Mysteries could be, but from one stage to the next initiates did not necessarily progress, it is thought a good deal of confessing was required, applicants were auditioned for suitability and it is thought that the low high-level initiation achievement was as a result of moral unsuitability. The blood of a sacrificial animal was used in baptismal rites for either the initiate or the priest by proxy. This recalls the blood baptism described by initiates in the cult of Mithras.

\section{THE POWER OF SYMBOLS}

In studying centuries old initiation techniques we can find common symbols and systems that still have transformative power, that still resonate with our collective unconscious. We are surrounded by symbols and meaning in every moment of life, but our connection to the deeper significance of these symbols is buried beneath a strong attachment to material reality. From street names, to brand logos to movie plots - the power of symbols to speak directly to the human psyche about its own nature has been watered down, or worse still - polluted and confused. We might explore these symbols and meanings in our dreams or in other altered states, but our waking awareness is so bombarded by a culture of distraction we often fail to see the meaning and significance in these ever-present stories and symbols. These symbols exist apart from ourselves in the normal world and therefore our ego preservation narrative persists.

If we break down the components of documented bliss, transcendental and 'one-ness' states, we often find cross-cultural themes and motifs. Is careful employment of motifs and themes sufficient to create awe in the one who witnesses them? Are these symbols so deeply interwoven within the fabric of human consciousness that our inner being will identify with them straight away?

\section{THE IMPACT OF RITUAL DRAMA}

The Mystery traditions of Ancient Egypt, Greece and Rome utilised ritual drama to connect deep myths to individual observers. After periods of fasting, long pilgrimages, dancing and sacrifice, supplicants found themselves in a state of consciousness whereby these ritual dramas and pageants made a profound impact upon the psyche. Drama is designed to become entangled with our emotions and perception of reality.

\section{THE IMPACT OF CONTEMPORARY MEDIA}

Contemporary media, with its trash TV, endless advertising, social networking and corporate agenda is often a polluting force. The impact of modern media on human consciousness and mental health is underestimated. Our ancestors had a necessarily select exposure to drama and every aspect of it was carefully considered.

\section{DATA MINING REVEALS SIX BASIC EMOTIONAL ARCS WITHIN STORYTELLING}

A steady, on-going rise in emotional valence, such as Alice's Adventures Underground by Lewis Carroll. A steady on-going fall in emotional valence, as in a tragedy such as Romeo and Juliet. A fall then a rise, such as the man-in-a-hole story, discussed by Vonnegut. A rise then a fall, such as the Greek myth of Icarus. Rise-fall-rise, such as Cinderella. Fall-rise-fall, such as Oedipus. The most popular and impactful are stories that follow the Icarus and Oedipus arcs and stories that follow more complex arcs that use the basic building blocks in sequence. This empirical evidence provides an important insight into the nature of storytelling and its appeal to the human psyche. In neuroscience, long-term changes in brain connectivity are shown to persist for several days upon reading fiction. These changes have been observed in bilateral somatosensory cortex, suggesting a potential mechanism for "embodied semantics." So here we see that 'imagining' an action is activating the same regions involved in actually 'doing' the action.

\section{TECHNOLOGY UTILISED FOR THE SEVENTH RAY EXPERIENCE}

Mixed Reality gives us the opportunity to play with perception and identity. During the Seventh Ray we 
explore 'out-of-body' sensations (Outraspectre), using somatic technology and the Koren/Persinger's God/Shiva Helmet.

In addition, the Holoportal at Ravensbourne (https://www.ravensbourne.ac.uk/news/2016/12/rav ensbourne-and-doubleme-launch-the-uk-s-firstholoportal/) provides us with an opportunity to enrich and vivify visual content within a constructed scene and expand one's consciousness beyond the boundaries set by the limitations of ordinary media and the normal human senses. One example being the ability to observe the micro and macro world simultaneously. This boundary dissolution is a vital aspect of the transcendental experience. For example as the participant watches their hand, observing its structure, shape and size in relationship to the rest of the body, they are simultaneously able to observe its molecular and atomic make-up, witnessing cells, atoms and DNA and the infinite space of the quantum world. Within this space, entire universes start to appear.

\section{MEASURING THE IMPACT OF THE SEVENTH RAY INITIATION EXPERIENCE}

Aside from collecting reports before and after the participant has had the experience, we measure using certain biomarkers of the participant such as Heart rate, Galvanic Skin Response, temperature and EEG in order to identify the physiological effects of the experience.

\section{REFERENCES}

Bendit, L. J. (1973) The Mysteries Today and other essays. The Theosophical Publishing House.

Dee, N, (1989) The Dreamer's Workbook. The Aquarian Press.

Diem Lane, A. (2015) The Gnostic Mystery. Mt. San Antonio College.

Feinstein, D. and Krippner, S. (1988) Personal Mythology: The Psychology of Your Evolving Self.

Feinstein, D. and Krippner, S. (1997) The Mythic Path. Jeremy P. Tarcher/Putnam.

Graves, R. (1955) The Greek Myths Vol. I \& II. Penguin.

Jaynes, J. (1976) The Origin of Consciousness in the Breakdown of the Bicameral Mind. Houghton Mifflin/Mariner Books.
Jung, C. G. (1973) Psychological Reflections: An anthology of Jung's Writings.

McIntosh, C. (1980) The Rosicrucians: The History and Mythology of an Occult Order. Crucible.

Meier, C. A. (1989) Healing Dream and Ritual: Ancient Dream Incubation and Modern Psychotherapy. Daimon Verlag,

Ornstein, R. (1991) The Evolution of Consciousness: Of Darwin, Freud, Cranial Fire The Origins of the Way We Think. Prentice Hall Press.

Rundle Clark, R. T. (1978) Myth and Symbol in Ancient Egypt. Thames and Hudson.

Steiner, R. (1910-1913) The Four Mystery Dramas.

Steiner, R. (1947) The World of the Senses and the World of the Spirit: Six lectures given at Hanover 27th December 1911 - 1st January 1912. Rudolf Steiner Publishing House.

Steiner, R. (1947) Knowledge of the Higher Worlds. Rudolf Steiner Publishing House.

Steiner, R. (1971) Ancient Myths: Their Meaning and Connection with Evolution. Steiner Book Centre.

Steiner, R. (1910-1911) Occult History, Six Lectures in Stuttgart.

Tamir, D. L. (2015) Reading fiction and reading minds: the role of simulation in the default network.

Temple, R. K. G. (1984) Conversations with Eternity: Ancient Man's Attempts to Know the Future. Rider, London.

The Three Initiates (1908) The Kybalion.

The Corpus Hermeticum (1999) The Definitions of Hermes (translation by Jean-Pierre Mahe).

Wallis Budge, E. A. (1920) The Book of the Dead (translation of the Egyptian Book of Coming Forth by Day).

Wasson, R. G., Hofmann, A., Ruck, C. A. P. (1978) Road to Eleusis: Unveiling the Secret of the Mysteries. North Atlantic Books.

Williams, L. and Pearce, D. (2005) Inside the Neolithic Mind: Consciousness, Cosmos and the Realm of the Gods. Thames and Hudson.

Wilson, C. and Grant, J. (1981) The Directory of Possibilities. Webb and Bower. 